\title{
Grammar of the Mexican Language
}

\author{
Nahuatl Studies Series
}

Number 7

\author{
Series Editor \\ James Lockhart \\ Associate Series Editor \\ Rebecca Horn
}




\section{UCLA Latin American Studies}

Volume 89 


\section{G R A M M A R $\mathrm{OF}$}

\section{THE MEXICAN LANGUAGE}

WITH AN EXPLANATION OF ITS ADVERBS

(1645)

By

Horacio Carochi, S. J.

translated and edited with commentary by James Lockhart

Stanford University Press

UCLA Latin American Center Publications 


\section{Stanford University Press}

Stanford, California

C 2001 by the Board of Trustees of the Leland Stanford Junior University

Printed in the United States of America on acid-free, archival-quality paper

Library of Congress Cataloging-in-Publication Data

Carochi, Horacio.

[Compendio del arte de la lengua mexicana. English]

Grammar of the Mexican language : with an explanation of its adverbs (1645) / by Horacio Carochi ; translated and edited with commentary by James Lockhart.

p. cm. - (Nahuatl studies series ; no. 7)

"In this edition the original, with its Spanish and Nahuatl, faces an English translation of the Spanish and a second version of the Nahuatl examples"-Pref.

Includes bibliographical references and indexes.

ISBN 0-8047-4281-2 (alk. paper)

1. Nahuatl language-Grammar. 2. Nahuatl language-Adverb.

I. Lockhart, James. II. Title. III. Nahuatl series ; no. 7.

PM4063.C313 2001

497'.45282421-dc21

Original Printing 2001

Last figure below indicates year of this printing:

$\begin{array}{llllllllll}10 & 09 & 08 & 07 & 06 & 05 & 04 & 03 & 02 & 01\end{array}$ 